Biochimica et Biophysica Acta, 618 (1980) 223-230

(C) Elsevier/North-Holland Biomedical Press

BBA 57562

\title{
BASE-EXCHANGE REACTIONS OF THE PHOSPHOLIPIDS IN CARDIAC MEMBRANES
}

\author{
DAVID A. FILLER, and PAUL A. WEINHOLD
}

Veterans Administration Medical Center and Department of Biological Chemistry, University of Michigan Medical School, 2215 Fuller Road, Ann Arbor, MI 48105 (U.S.A.)

(Received July 16th, 1979)

(Revised manuscript received December 7th, 1979)

Key words: Phospholipid; Base exchange; Cation stimulation; Membrane-bound $\mathrm{Ca}^{2+}$;

(Canine cardiac microsome)

\section{Summary}

Canine cardiac microsomes were shown to incorporate the nitrogenous bases, serine, ethanolamine, and choline, into their respective phospholipids by the energy-independent, $\mathrm{Ca}^{2+}$-stimulated base-exchange reactions. The optimal $\mathrm{Ca}^{2+}$ concentration was $2.5 \mathrm{mM}$. Metal ions other than $\mathrm{Ca}^{2+}$ either inhibited or had no effect on the activities. $\mathrm{La}^{3+}$ and $\mathrm{Mn}^{2+}$ were both potent inhibitors. The $\mathrm{pH}$ optimum for the reactions at $2.5 \mathrm{mM} \mathrm{Ca}^{2+}$ was approx. 7.8 and depended upon $\mathrm{Ca}^{2+}$ concentration. Apparent $K_{\mathrm{m}}$ values at $2.5 \mathrm{mM} \mathrm{Ca}^{2+}$ were $0.06 \mathrm{mM}$ for L-serine, $0.13 \mathrm{mM}$ for ethanolamine and $0.49 \mathrm{mM}$ for choline. The kinetic and metal ion inhibition studies suggest that the choline-exchange reaction is a separate process from the serine and ethanolamine reactions. The ATPstimulated $\mathrm{Ca}^{2+}$ binding system of the cardiac membranes was not related to the base-exchange reactions; however, the energy-independent $\mathrm{Ca}^{2+}$ binding to the membranes appears to be related to the exchange reactions.

\section{Introduction}

The incorporation of serine, ethanolamine and choline into phospholipids can occur by a $\mathrm{Ca}^{2+}$-dependent, energy-independent exchange with the base of an existing phospholipid [1]. Although these reactions have been demonstrated in vitro in several mammalian tissues $[2-6]$, their in vivo significance is uncer- 
tain [7-11]. The serine exchange reaction is, however, the only known pathway for the biosynthesis of phosphatidylserine in mammalian tissues $[3,12]$.

The specialized role of cardiac membranes in the regulation of intracellular $\mathrm{Ca}^{2+}$ concentrations $[13-16]$, coupled with the fact that the $\mathrm{Ca}^{2+}$-binding and transport systems have a requirement for acidic phospholipids such as phosphatidylserine [17-22], raise the possibility that the $\mathrm{Ca}^{2+}$-dependent baseexchange reactions in the membranes may function to regulate the $\mathrm{Ca}^{2+}$-binding properties through a modification of the phospholipid composition at specific sites in the membranes. In order to explore this possibility in more detail, we have characterized the $\mathrm{Ca}^{2+}$-dependent base-exchange reactions in cardiac microsomes and compared them to $\mathrm{Ca}^{2+}$ binding properties. 'I'he results of these studies are presented in this paper.

\section{Experimental}

Materials. $\mathrm{L}-\left[\mathrm{U}-{ }^{14} \mathrm{C}\right]$ Serine, $\left[1,2 \cdot{ }^{14} \mathrm{C}\right]$ ethanolamine hydrochloride, $\left[\mathrm{Me}-{ }^{14} \mathrm{C}\right]-$ choline chloride, ${ }^{45} \mathrm{CaCl}_{2}$ and Aquasol were purchased from $\mathrm{New}$ England Nuclear. All other chemicals were of reagent grade and were obtained from commercial supply houses.

Preparation of cardiac microsomes. The cardiac microsomes were prepared by the modification and combination of the methods of Krasnow [23] and Harigaya and Schwartz [24]. Mongrel dogs obtained from Meadowbrook Farms (Detroit, MI) were anesthetized with $60 \mathrm{mg} / \mathrm{kg}$ pentobarbital intravenously. The beating heart was excised, chilled in crushed ice, and freed of extrancous tissue. All subsequent steps were performed at $4^{\circ} \mathrm{C}$.

The ventricles were cut into small pieces, washed with $0.3 \mathrm{M}$ sucrose, $10 \mathrm{mM}$ Hepes ( $\mathrm{pH} 7.4$ ), ground in a meat grinder, and homogenized in a Waring Blendor for $35 \mathrm{~s}$ in 3 vols. $0.3 \mathrm{M}$ sucrose, $10 \mathrm{mM}$ Hepes ( $\mathrm{pH} 7.4$ ). The $\mathrm{pH}$ of the homogenate was readjusted to $\mathrm{pH} 7.4$ with $6 \mathrm{~N} \mathrm{NaOH}$. The homogenate was centrifuged at $13000 \times \mathrm{g}$ for $30 \mathrm{~min}$ and the pellet discarded. A microsomal preparation was prepared from the supernatant by centrifugation for $45 \mathrm{~min}$ at $100000 \times \mathrm{g}$. The microsomal pellet was suspended in $0.3 \mathrm{M}$ sucrose, $10 \mathrm{mM}$ Hepes (pH 7.4) to obtain a protein concentration of $10 \mathrm{mg} / \mathrm{ml}$. The microsomal preparation was stored at $-80^{\circ} \mathrm{C}$ and was stable for several months.

Base-exchange assays. The assay of base incorporation was a modification of the method of Kanfer [4]. The standard incubation media contained 1.2$1.9 \mathrm{mg} / \mathrm{ml}$ microsomal protein, $50 \mathrm{mM}$ Hepes (pH 7.8), $2.5 \mathrm{mM} \mathrm{CaCl}_{2}$ and base substrate in a total volume of $0.2 \mathrm{ml}$. The standard concentration of base for serine incorporation was $0.1 \mathrm{mM} \mathrm{L}-\left[\mathrm{U}-{ }^{14} \mathrm{C}\right]$ serine $(12 \mathrm{Ci} / \mathrm{mol})$, for ethanolamine incorporation $0.13 \mathrm{mM}\left[1,2-{ }^{14} \mathrm{C}\right]$ ethanolamine $(2 \mathrm{Ci} / \mathrm{mol})$, and for choline incorporation $0.5 \mathrm{mM}\left[\mathrm{Me}^{-14} \mathrm{C}\right] \mathrm{choline}(11 \mathrm{Ci} / \mathrm{mol})$. The incorporation was started by the addition of microsomal protein and incubated at $37^{\circ} \mathrm{C}$ in a water bath. The incubation time for serine incorporation was $2 \mathrm{~min}$, for ethanolamine $8 \mathrm{~min}$, and for choline $6 \mathrm{~min}$. The reaction was stopped, the total lipids extracted, and the extract washed by the method of Folch et al. [25]. The washed solvent phase was transferred to a scintillation vial and evaporated to dryness. Controls containing no microsomal protein or calcium or with zero time of incubation were included with each experiment. The base incorpora- 
tion was calculated for the amount of radioactivity incorporated into the total lipid extract and the specific activity of the base substrate. Radioactivity incorporated in the control samples was subtracted from the other samples in each experiment. The rate of incorporation of ethanolamine, choline and serine was constant for $15 \mathrm{~min}, 5 \mathrm{~min}$ and $3 \mathrm{~min}$, respectively. The rate of reaction was proportional to protein up to $2 \mathrm{mg} / \mathrm{ml}$.

$\mathrm{Ca}^{2+}$ binding and uptake. $\mathrm{Ca}^{2+}$ binding and uptake assays were a modification of the methods used by Sulakhe et al. [26]. For $\mathrm{Ca}^{2+}$ binding the standard incubation medium contained $0.02-0.10 \mathrm{mg} / \mathrm{ml}$ microsomal protein, $50 \mathrm{mM}$ Tris-maleate (pH 6.7), $5 \mathrm{mM} \mathrm{MgCl}_{2}, 5 \mathrm{mM} \mathrm{ATP}$ and $0.1 \mathrm{mM}^{45} \mathrm{CaCl}_{2}(5000-$ $10000 \mathrm{cpm} / \mathrm{nmol}$ ) in a final volume of 1 or $2 \mathrm{ml}$. The assay was started by the addition of microsomes, incubated for $2 \mathrm{~min}$ at $37^{\circ} \mathrm{C}$, and terminated by filtering with suction a $0.2 \mathrm{ml}$ aliquot through a $0.2 \mathrm{~mm}$ filter $(25 \mathrm{~mm}$ type GS Millipore). The filter was washed with $5 \mathrm{ml}$ cold $50 \mathrm{mM}$ Tris-maleate ( $\mathrm{pH} \mathrm{6.7)}$ and placed in a scintillation vial containing $10 \mathrm{ml}$ Aquasol. The radioactivity retained by the microsomes on the filter was determined and the $\mathrm{Ca}^{2+}$ binding was calculated using the specific activity of the added ${ }^{45} \mathrm{CaCl}_{2}$. Controls containing no ATP and no protein were included. No $\mathrm{Ca}^{2+}$ was bound to the filters in the absence of microsomes. The medium for $\mathrm{Ca}^{2+}$ uptake was the $\mathrm{Ca}^{2+}$ binding medium with $5.0 \mathrm{mM}$ potassium oxalate added. The microsomes were preincubated at $37^{\circ} \mathrm{C}$ in the media without ${ }^{45} \mathrm{CaCl}_{2}$ for $4 \mathrm{~min}$. The uptake was started by the addition of $0.1 \mathrm{mM}{ }^{45} \mathrm{CaCl}_{2} \quad(5000-10000 \mathrm{cpm} / \mathrm{nmol})$, incubated for $2 \mathrm{~min}$ at $37^{\circ} \mathrm{C}$, and terminated as described for the binding assay. The preincubation led to a 35-40\% increase in the $\mathrm{Ca}^{2+}$ uptake. The $\mathrm{Ca}^{2+}$ uptake was calculated by methods similar to those described for binding. Controls containing no ATP or incubated for zero time gave an insignificant amount of uptake.

Energy-independent $\mathrm{Ca}^{2+}$ binding was determined by the Millipore filtration technique except the $\mathrm{pH}$ was 7.8 and $\mathrm{Mg}^{2+}$ and ATP were omitted from the reaction mixture. Binding was also determined by equilibrium dialysis. In this

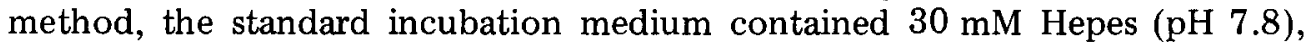
$0.1 \mathrm{mM}{ }^{45} \mathrm{CaCl}_{2}(5000-10000 \mathrm{cpm} / \mathrm{nmol})$ and $0.8-1.0 \mathrm{mg} / \mathrm{ml}$ microsomal protein in a total volume of $0.2 \mathrm{ml}$. The dialysis was performed in an 8-place equilibrium dialysis cell with $0.5 \mathrm{ml}$ chambers (model 377 , Bel-Art Products). The chambers were separated with sheets of cellulose dialysis membranes (pore size $0.28 \mathrm{~nm}$ ). Opposing chambers contained similar incubation medium without microsomal protein added. The dialysis cell was rotated slowly at $4^{\circ} \mathrm{C}$ for 20-24 h. A $0.1 \mathrm{ml}$ aliquot was withdrawn from each chamber and placed in a scintillation vial containing $10 \mathrm{ml}$ of Aquasol. The radioactivity was determined, and the $\mathrm{Ca}^{2+}$ binding was calculated from the difference in radioactivity in opposing chambers.

Analysis of phospholipids. Phospholipids were separated by thin-layer chromatography on Silica gel $60 \mathrm{HR}$ plates with $\mathrm{CHCl}_{3} / \mathrm{CH}_{3} \mathrm{OH} / \mathrm{CH}_{3} \mathrm{COOH} /$ $\mathrm{H}_{2} \mathrm{O}(25: 15: 4: 2, \mathrm{v} / \mathrm{v})$. Glycerylphosphoryl bases were prepared by mild alkaline methanolysis of the total lipid extract as described by Dawson [27]. The glycerylphosphoryl bases were separated on $\mathrm{Q} 2 \mathrm{~F}$ cellulose thin-layer plates (Quantum Industries) with phenol/0.12\% $\mathrm{NH}_{4}(25: 35, \mathrm{v} / \mathrm{v})$.

Analytical methods. Protein was determined by the method of Lowry et al. 
[28] with bovine serum albumin as standard.

Radioactivity measurements were made in a liquid scintillation spectrometer.

Results

\section{Characteristics of base-exchange reactions}

Cardiac microsomes incorporate radioactive choline, ethanolamine and serine into phospholipids when incubated with $\mathrm{Ca}^{2+}$. Ethanolamine was incorporated at the highest rate, followed by serine and choline. The reaction was dependent upon $\mathrm{Ca}^{2+}$ and was unaffected by ATP or CTP. The $\mathrm{pH}$ optimum was determined to be $7-8$ for the three base-exchange reactions at $\mathrm{Ca}^{2+}$ concentrations of $2.5 \mathrm{mM}$. This value is the same as reported for liver [9] and brain [31]. The $\mathrm{pH}$ optimums were shifted to slightly higher $\mathrm{pH}$ values when the reactions were done at $0.2 \mathrm{mM} \mathrm{Ca}^{2+}$. A similar $\mathrm{Ca}^{2+}$-dependent shift in $\mathrm{pH}$ optimum has been reported with liver microsomes $[9,29]$.

Double-reciprocal plots of base concentrations and $\mathrm{Ca}^{2+}$ concentrations vs. velocity were linear. The apparent $K_{\mathrm{m}}$ values and maximal velocities are shown in Table I. The apparent $K_{\mathrm{m}}$ for base incorporation was lowest for serine and highest for choline. The $V$ for ethanolamine was approx. five times higher than for serine and choline. The apparent $K_{\mathrm{m}}$ for $\mathrm{Ca}^{2+}$ was essentially the same for the three reactions. Each base was a competitive inhibitor for the incorporation of the other bases. Their relative potency as inhibitors was similar to their relative apparent $K_{\mathrm{m}}$ values. Serine was the most potent inhibitor with a $K_{\mathbf{i}}$ value of $0.11 \mathrm{mM}$ for the inhibition of both ethanolamine and choline incorporation. Ethanolamine inhibition was also similar for both serine and choline incorporation ( $K_{\mathrm{i}}$ of $0.33 \mathrm{mM}$ and $0.51 \mathrm{mM}$, respectively). However, the inhibition by choline of serine and ethanolamine incorporation was considerably different ( $K_{\mathrm{i}}$ of 0.64 and $6.9 \mathrm{mM}$, respectively).

\section{Phosphatidylserine decarboxylation}

Radioactive choline and ethanolamine were incorporated exclusively into their corresponding phospholipids as judged by both thin-layer chromatography of the lipids and by separation of the glycerylphosphoryl bases after methanolysis. The major portion of $\left[\mathrm{U}-{ }^{14} \mathrm{C}\right]$ serine was incorporated into phosphatidylserine, however, a small but reproducible amount of radioactivity was incorporated into phosphatidylethanolamine ( $2 \%$ of the total incorporated).

\section{TABLE I}

$K_{\mathrm{m}}$ AND $V$ VALUES FOR BASE EXCHANGE

The values are averages \pm S.E. for the number of determinations (shown in parentheses). Each value was from an enzyme preparation from a different animal. $\mathrm{Ca}^{2+}$ was maintained at $2.5 \mathrm{mM}$ when base concentrations were varied.

\begin{tabular}{llll}
\hline Kintetic constant & \multicolumn{2}{l}{ Substrate } & \\
\cline { 2 - 4 } & Serine & Ethanolamine & Choline \\
\hline Substrate $K_{\mathrm{m}}(\mathrm{mM})$ & $0.06 \pm 0.01(5)$ & $0.13 \pm 0.04(5)$ & $0.49 \pm 0.07(3)$ \\
$V(\mathrm{nmol} / \mathrm{min}$ per $\mathrm{mg})$ & $0.44 \pm 0.08(3)$ & $2.18 \pm 0.09(4)$ & $0.45 \pm 0.04(3)$ \\
$\mathrm{Ca}^{2+} K_{\mathrm{m}}(\mathrm{mM})$ & $0.22 \pm 0.09(11)$ & $0.36 \pm 0.22(4)$ & $0.39 \pm 0.23(3)$ \\
\hline
\end{tabular}


Furthermore, the use of $\left[1-{ }^{14} \mathrm{C}\right]$ serine resulted in a 3 -fold decrease in the amount of incorporation of radioactivity into phosphatidylethanolamine. Thus, the microsomal preparation apparently contains some phosphatidylserine decarboxylase activity. The $\mathrm{Ca}^{2+}$-dependent incorporation of serine into phospholipid was considerably less in mitochondria than in microsomes $(2.1 \mathrm{nmol} /$ mg protein for microsomes vs. $0.09 \mathrm{nmol} / \mathrm{mg}$ protein for mitochondria after $35 \mathrm{~min}$ of incubation). However, $32 \%$ of the radioactivity incorporated by mitochondria was in phosphatidylethanolamine. These data suggest that mitochondria have a relatively low base-exchange activity but contain relatively active phosphatidylserine decarboxylase activity. This result is consistant with previous studies with liver and brain [30,31]. The small amount of decarboxylase activity in the microsomes may result from mitochondrial contamination. However, since no independent assessment of mitochondrial contamination was made, the occurrence of phosphatidylserine decarboxylase in microsomes cannot be completely discounted.

Relationship between base-exchange reactions and $\mathrm{Ca}^{2+}$ binding and transport systems

The observation that ATP did not stimulate the base-exchange reaction even at low concentrations of $\mathrm{Ca}^{2+}$ suggests that binding of $\mathrm{Ca}^{2+}$ by the ATP. stimulated process in cardiac microsomes was not related to the base-exchange reaction. Furthermore, the optimum $\mathrm{pH}$ for ATP-stimulated $\mathrm{Ca}^{2+}$ binding is approx. 6.7 [28], whereas the $\mathrm{pH}$ optimum for the base-exchange reaction is 7.8. EGTA has been shown to extract a number of $\mathrm{Ca}^{2+}$ binding proteins from sarcoplasmic reticulum, many of which are associated with the ATP-stimulated $\mathrm{Ca}^{2+}$ binding and uptake [32-35]. Cardiac microsomes were isolated as described in Experimental except that half of the $100000 \times \mathrm{g}$ pellet was resuspended in $0.3 \mathrm{M}$ sucrose, $2.5 \mathrm{mM}$ EGTA, $10 \mathrm{mM}$ Hepes ( $\mathrm{pH} 7.8$ ). This was allowed to stand with stirring at $4^{\circ} \mathrm{C}$ for $30 \mathrm{~min}$. The other half of the pellet was prepared according to the standard procedure. The EGTA-extracted microsomes were centrifuged at $100000 \times \mathrm{g}$ for $45 \mathrm{~min}$ and from that point the preparation was processed according to the standard procedure. The EGTA extraction had very little effect on the apparent $\mathrm{Ca}^{2+} K_{\mathrm{m}}$ values for baseexchange; however, the $\mathrm{Ca}^{2+} K_{\mathrm{d}}$ for the ATP-stimulated $\mathrm{Ca}^{2+}$ binding was more than tripled (Table III).

The $K_{\mathrm{d}}$ for energy-independent $\mathrm{Ca}^{2+}$ binding was $0.20 \mathrm{mM}$ and $0.37 \mathrm{mM}$ as measured by Millipore and dialysis, respectively. The $K_{\mathrm{d}}$ for $\mathrm{Ca}^{2+}$ is very similar

TABLE II

EFFECT OF EGTA ON CALCIUM $\kappa_{m}$ FOR THE BASE-EXCHANGE REACTIONS

All determinations were performed at $\mathrm{pH} 7.8$.

\begin{tabular}{lllll}
\hline Microsomes & \multicolumn{2}{l}{ Base-exchange $\mathrm{Ca}^{2+} K_{\mathrm{m}}(\mathrm{mM})$} & & $\begin{array}{l}\text { ATP calcium- } \\
\text { binding } K_{\mathrm{d}} \\
\text { (mM) }\end{array}$ \\
\cline { 2 - 5 } & Serine & Ethanolamine & Choline & 0.15 \\
\hline Control & 0.11 & 0.13 & 0.20 & 0.06 \\
EGTA-extracted & 0.09 & 0.13 & 0.20 \\
\hline
\end{tabular}


SERINE INCORPORATION VS. CALCIUM CALCIUM BINDING VS. CALCIUM
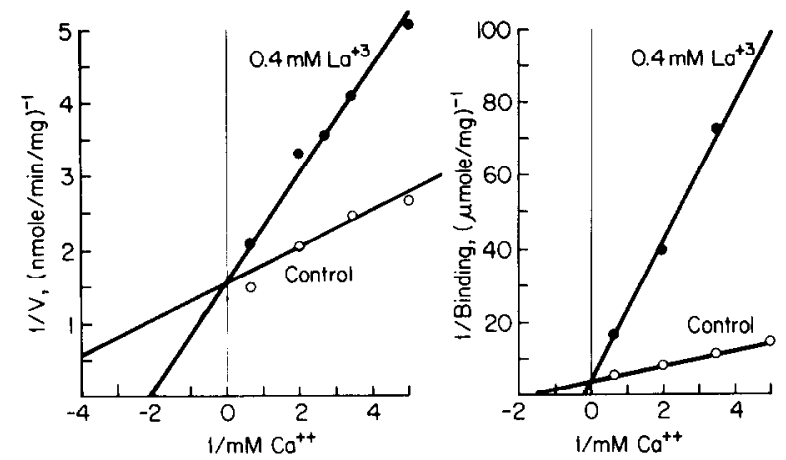

Fig. 1. Effect of $\mathrm{La}^{3+}$ on serine incorporation on energy-independent calcium binding. The standard incubation medium for serine incorporation contained $0.2 \mathrm{mM}$ serine, $30 \mathrm{mM}$ Hepes ( $\mathrm{pH} 7.3$ ) and $\mathrm{La}^{3+}$ as indicated. Calcium binding was determined by equilibrium dialysis. Each point is an average of three assays.

to the apparent $K_{\mathrm{m}}$ for $\mathrm{Ca}^{2+}$ in the serine-exchange reaction (Table I), suggesting that a major portion of the energy-independent binding of $\mathrm{Ca}^{2+}$ may be related to the base-exchange reaction. All three exchange reactions were strongly inhibited by $\mathrm{Mn}^{2+}$ and $\mathrm{La}^{3+}$. The effects of $\mathrm{La}^{3+}$ on both the $\mathrm{Ca}^{2+}$ binding and the serine-exchange reactions are shown in Fig. 1. $\mathrm{La}^{3+}$ competitively inhibited $\mathrm{Ca}^{2+}$ binding, a result in agreement with other reports [36-38]. $\mathrm{La}^{3+}$ also appears to competitively inhibit the serine-exchange reaction, thus providing additional evidence that the energy-independent $\mathrm{Ca}^{2+}$ binding sites are closely associated with the base-exchange reactions. $\mathrm{Mn}^{2+}$, however, was an uncompetitive inhibitor of $\mathrm{Ca}^{2+}$ binding (Fig. 2) and showed mixed inhibition towards serine-base exchange. Although the kinetics of $\mathrm{Mn}^{2+}$ inhibition of serine-exchange reaction were not strictly competitive, a strong tendency towards competitive inhibition was apparent.
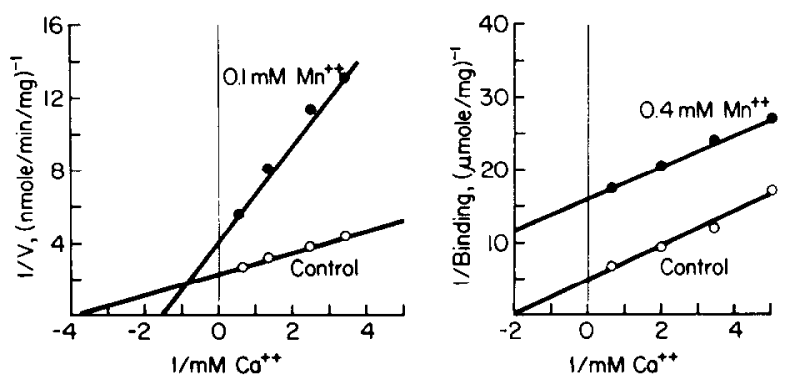

Fig. 2. Effect of $\mathrm{Mn}^{3+}$ on serine incorporation and energy-independent calcium binding. The standard incubation medium for serine incorporation contained $0.2 \mathrm{mM}$ serine, $30 \mathrm{mM}$ Hepes $(\mathrm{pH} 7.8)$ and $\mathrm{Mn}^{2}+$ as indicated. Calcium binding was determined by equilibrium dialysis. Each point is an average of three assays. 


\section{Discussion}

The base-exchange reactions have been reported to occur in a variety of tissues. Although Kiss [39] has reported that L-serine is incorporated into phosphatidylserine by rat heart homogenates by a $\mathrm{Ca}^{2+}$-dependent process, a complete characterization of the base-exchange reactions in heart has not previously been made. In the present work, canine cardiac microsomes which contain the ATP-stimulated calcium binding and transport were also shown to incorporate the nitrogenous bases, serine, ethanolamine, and choline, into their respective phospholipids by the energy-independent, calcium-stimulated baseexchange reactions. The characteristics of these reactions in heart microsomes were for the most part similar to those reported for other tissues.

The $\mathrm{Ca}^{2+}$ binding sites on the membranes that are associated with the active transport of $\mathrm{Ca}^{2+}$ apparently are not related to the $\mathrm{Ca}^{2+}$-dependent base exchange reactions. However, the energy-independent binding of $\mathrm{Ca}^{2+}$ to the membranes is related to the $\mathrm{Ca}^{2+}$-dependent base-exchange reactions. The exact nature of these sites is unknown. The competitive inhibition by $\mathrm{La}^{3+}$ suggests that the sites may be related to a divalent cation carrier system since $\mathrm{La}^{3+}$ has been shown to block the cation process in other tissues [40].

Although the synthesis of phospholipids by muscle tissue has not been extensively studied, sarcoplasmic reticulum membranes from skeletal muscle have been shown by Sarzala and Pilanska [41] to synthesize phospholipids by the same pathways as endoplasmic reticulum of other tissues. Similar studies with cardiac sarcoplasmic reticulum membranes have not been reported. Our results demonstrate that cardiac membranes synthesize phosphatidylserine by the same pathway that occurs in other mammalian tissues, i.e. the $\mathrm{Ca}^{2+}$-dependent exchange. The significance of the other base-exchange reactions is less clear but may be important in altering or maintaining the microenvironment at specific positions in membranes.

\section{Acknowledgements}

This work was supported by the Veterans Administration and by Grant HL 15766 from the National Heart and Lung Institute.

\section{References}

1 Dils, R.R. and Hubscher, G. (1961) Biochim. Biophys. Acta 46, 505-513

2 Hubscher, G. (1962) Biochim. Biophys. Acta 57, 555-561

3 Porcellati, G., Arienti, G., Pirotta, M. and Giorgini, D. (1971) J. Neurochem. 18, 1395-1417

4 Kanfer, J.N. (1972) J. Lipid Res. 13, 408-476

5 Lunt, G.G, and Lapetina, E.G. (1970) Brain Res. 18, 451-459

6 Taki, T. and Matsumoto, M. (1973) Jap. J. Exp. Med. 431, 219-226

7 Stein, D. and Stein, Y. (1969) J. Cell Biol. 40, 461-483

8 Sundler, R. (1973) Biochim. Biophys. Acta 306, 218-226

9 Bjerve, K.S. (1973) Biochim. Biophys. Acta 296, 549-562

10 Bjerve, K.S. and Bremer, J. (1969) Biochim. Biophys. Acta 176, 570-583

11 Treble, D.H., Frumkin, S., Ballint, J.A. and Beeler, D.A. (1970) Blochim. Biophys. Acta 202, 103171

12 Borkenhagen, L.F., Kennedy, E.P. and Fielding, L. (1961) J. Biol. Chem. 236, PC 28-30

13 Ebashi, S. and Endo, M. (1968) Prog. Biophys. Mol. Biol. 18, 123-183 
14 Martonosi, A., Pucell, A.G. and Halpin, R.A. (1971) in Cellular Mechanisms for Calcium Transfer and Homeostasis (Nichols, G., Jr. and Wasserman, R.H., eds.), pp. 175-191, Academic Press, New York

15 Inesi, G. (1972) Ann. Rev. Biophys. Bioeng. 1, 191-210

16 Berridge, M.J. (1975) in Advances in Cyclic Nucleotide Research (Greengard, P. and Robinson, G.A., eds.), Vol. 6, pp. 46-52, Raven Press, New York

17 Carvallo, A.P. (1972) Eur. J. Biochem. 27, 291-302

18 Meissner, G. and Fleischer, S. (1972) Biochim. Biophys. Acta 255, 19-33

19 Martonosi, A., Donley, J.R., Pucell, A.G. and Halpin, R.A. (1971) Arch. Biochem. Biophys. 114, $529-540$

20 Martonosi, A., Donley, J.R. and Halpin, R.A. (1968) J. Biol. Chem. 243,61-70

21 Fiehn, W. and Hasslbach, W. (1970) Eur. J. Biochem. 13, 510-518

22 Steinberg, J., Masoro, E.J. and Yu, D.P. (1974) J. Lipid Res. 15, 537-543.

23 Krasnow, N. (1972) Biochim. Biophys. Acta 282, 187-194

24 Harigaya, S. and Schwartz, A. (1969) Circ. Res. 25, 781-794

25 Folch, J., Lees, M. and Sloane Stanley, G.H. (1957) J. Biol. Chem. 226, 497-509

26 Sulakhe, P.V., Drummond, G.I., and Ng, D.C. (1973) J. Biol. Chem. 248, 4150-4157

27 Dawson, R.M.C. (1967) in Lipid Chromatographic Analysis (Marinetti, G.V., ed.), Vol, I, pp. 163189, Marcel Dekker, New York

28 Lowry, O.H., Rosebrough, N.J., Farr, A.L. and Randall, R.J. (1951) J. Biol. Chem. 193, 265-275

29 Gaiti, A., Demedio, G.E., Brunetti, M., Amaducci, L. and Porcellati, G. (1974) J. Neurochem. 23, 1153-1159

30 Borkenhagen, L.F., Kennedy, E.P. and Fielding, L. (1961) J. Biol. Chem. 236, PC 28-29

31 Wilson, J.D., Kenneth, D.G. and Udenfriend, S. (1960) J. Biol. Chem. 235, 3539-3543

32 Martonosi, A. and Duggan, P. (1970) J. Gen. Physiol. 56, 147-167

33 MacLennan, D. and Wong, P. (1971) Proc. Natl. Acad. Sci. U.S.A. 68, 1231-1 235

34 Thorley-Lawson, D. and Green, N. (1973) Eur. J. Biochem. 40, 403-413

35 Inesi, G. and Scales, D. (1974) Biochemistry 13,3298-3306

36 Sanborn, W. and Langer, G. (1970) J. Gen. Physiol. 56, 191-217

37 Ong, S. and Bailey, L. (1972) Experienta 28, 1446-1447

38 Naylor, W., Stone, J., Carson, V. and Chipperfield, D. (1971) J. Mol. Cell. Cardiol. 2, 125-143

39 Kiss, Z. (1976) Eur. J. Biochem. 67, 557-561

40 Mela, L. (1969) Biochemistry 8, 2481-2486

41 Sarzala, M.G. and Pilarska, M. (1976) Biochim. Biophys. Acta 441, 81-92 